\title{
TRANSPARANSI PELAYANAN IZIN INVESTASI USAHA DI KABUPATEN SINJAI
}

\author{
Mutahhara $^{1}$, Andi Luhur Prianto ${ }^{1}$, Muhammadiah ${ }^{2}$ \\ ${ }^{1}$ Program Studi Ilmu Pemerintahan Fakultas Ilmu Sosial dan Ilmu Politik \\ Universitas Muhammadiyah Makassar \\ Jl Sultan Alauddin No 259 Makassar 90221 \\ mutahhara@yahoo.co.id luhur@unismuh.ac.id \\ ${ }^{2}$ Program Studi Ilmu Adiministrasi Negara Fakultas Ilmu Sosial dan Ilmu Politik \\ Universitas Muhammadiyah Makassar \\ Jl Sultan Alauddin No 259 Makassar 90221 \\ muhammadiah@unismuh.ac.id
}

\begin{abstract}
This study aims to determine the transparency of permit services business investment in the district of Sinjai. This type of research is descriptive quantitative and qualitative approaches. Data analysis techniques In this study, researchers collected two types of data are quantitative and qualitative data. The results of this study show that: the government's efforts to be transparent in the body of investment and licensing services with the following indicators: integrity which a value or honesty in a container or the place where the implementation of a service process including the public service, and where there are also professionalism is where behavior or an individual's expertise in arranging a Yag systems exist in the work process, and there are also about constructive where to build awareness of employees who are to foster and build and improve so that in the process of service will occur transparency.
\end{abstract}

Keywords: transparency of services, business investment license.

\begin{abstract}
ABSTRAK
Penelitian ini bertujuan untuk mengetahui transparansi pelayanan izin investasi usaha di Kabupaten Sinjai. Jenis penelitian yang digunakan adalah pendekatan deskriptif kuantitatif dan kualitatif. Teknik analisis data Dalam penelitian ini, peneliti mengumpulkan dua jenis data yaitu kuantitatif dan data kualitatif. Hasil penelitian ini menunjukkan bahwa: upaya pemerintah agar transparan dibadan penanaman modal dan pelayanan perizinan dengan indikator yaitu: integritas yang dimana suatu nilai atau kejujuran dalam sebuah wadah atau tempat dimana terlaksanaya suatu proses pelayanan diantaranya adalah pelayanan publik,dan dimana terdapat juga profesionalisme adalah dimana tingkah laku atau keahlian seseorang didalam mengatur suatu sistem yag ada dalam proses kerja tersebut,dan ada juga tentang konstruktif yang dimana membangun kesadaran pegawai yang bersifat membina dan membangun dan memperbaiki sehingga dalam proses pelayanan akan terjadi transparansi.
\end{abstract}

Kata Kunci : transparansi pelayanan, izin investasi usaha. 


\section{A. PENDAHULUAN}

Badan Penanaman Modal dan Pelayanan Perizinan di Kabupaten Sinjai berperan sebagai pelaksana kebijakan daerah yang bersifat spesifik di bidang perizinan yanag mempunyai jasa pelayanan kepada masyarakat sejak masyarakat tersebut memutuskan untuk menggunakan Kantor Badan Penanaman Modal dan Pelayanan Perizinan, yang dimulai sejak masyarakat (pelanggan) mengurus surat izin di Kantor Badan Penanaman Modal dan Pelayanan Perizinan di Kabupaten Sinjai.

Keberhasilan suatu pelayanan tidak terlepas dari proses penyajian layanan yang diberikan berkaitan erat dengan janji Badan Penanaman Modal dan Pelayanan Perizinan di Kabupaten Sinjai terhadap masyarakat yang mengevaluasi layanan yang diterima sejak awal dan setelah layanan itu dirasakan. Bukti langsung yang dihadapi masyarakat menanamkan image Kantor Badan Penanaman Modal dan Pelayanan Perizinan di mata masyarakat sebagai realita dari Badan Penanaman Modal dan Pelayanan Perizinan di Kabupaten Sinjai tersebut.

Sejalan dengan arus reformasi yang berdampak terhadap tuntutan penyelenggaraan pemerintahan yang berorientasi pada transparansi dan akuntabilitas maka arah kebijakan pemerintah baik pusat maupun daerah berupaya untuk meningkatkan mutu pelayanan kepada masyarakat. Tuntutan dalam reformasi yang dilakukan oleh pemerintah berimplikasi pada perubahan kebijakan yang salah satunya mengenai kebijakan perubahan pada UndangUndang Pemerintahan Daerah No.32 Tahun 2004 dan Undang-Undang Penanaman Modal No.25 Tahun 2007.

Masalah Pelayanan Publik sudah diakomodir dalam suatu konsepsi dan strategi kebijakan di Kabupaten Sinjai mendatang yakni dengan isu bagaimana meningkatkan kualitas pelayanan publik tersebut dari tahun ke tahun yang disinyalir seakan-akan berjalan di tempat.

Adapun pelayanan yang dapat membantu Badan Penanaman Modal dalam memperoleh kemudahan izin investasi usaha yaitu PTSP (PelayananTerpadu Satu Pintu) yang dimana PTSP ini di maksudkan untuk membantu penanaman modal dalam memperoleh kemudahan pelayanan,fasilitas fiskal dan informasi mengenai penanaman modal dan proses perizinan akan dipermudah dengan meringkas prosedur.

Minimal ada 4 cakupan PTSPC Pelayanan Terpadu Satu Pintu Pertama, mencakup pelayanan semua jenis perizinan penanaman modal yang diperlukan untuk realisasi investasi,di sini diatur bagaimana pelayanan izin dilakukan. Kedua, pelayanan nonperizinan yang meliputi penerbitan rekomendasi. Rekomendasi dimaksud adalah visa izin tinggal terbatas, pemberian fasilitas fiscal dan non fiscal, serta pelayanan informasi. Ketiga adalah pelayanan pengaduan masyarakat atas hambatan pelayanan PTSP di bidang penanaman modal. Masyarakat berhak mengadukan hambatan-hambatan investasi agar segera dicarikan solusinya. Keempat, pelayanan kemudahan pelaksanaan kegiatan penanaman modal, termasuk memberikan bantuan atau fasilitas pelayanan perizinan dan non perizinan yang terkait dengan pelaksanaan penanaman modal.

Diundangkannya Undang-undang Nomor 25 Tahun 2007 tentang Penanaman Modal, maka Badan Koordinasi Penanaman Modal (BKPM) menjadi sebuah lembaga pemerintah yang menjadi koordinator kebijakan penanaman modal, baik koordinasi antar instansi pemerintah, pemerintah dengan Bank Indonesia, serta pemerintah dengan 
daerah maupun pemerintah daerah dengan pemerintah daerah. BKPM juga diamanatkan sebagai badan advokasi bagi para investor, misalnya menjamin tidak adanya ekonomi biaya tinggi.

Berkaitan dengan salah satu instansi pemerintah Daerah Kabupaten Sinjai yang menangani tentang pelayanan Izin Investasi Usaha Di Badan Penanaman Modal di anggap belum efektif dan belum berjalan dengan baik karena dalam peayanan masih terdapat kewenangan-kewenangan dan tindakan yang tidak terpuji, maraknya nepoteisme yang terjadi penguapan sehingga itu menciderai instansi usaha tersebut, dan membuat masyarakat hilang kepercayaan dan kecewa terhadap pelayanan tersebut melihat tidak selaras dengan Undang-Undang Nomor 25 Tahun 2007 dan Peraturan Mentri Dalam Negeri Nomor 24 Tahun 2006 Tentang Pedoman Penyelenggaraan Pelayanan terpadu satu pintu.

Selama ini instansi Badan penanaman modal dan pelayanan perizinan Kabupaten Sinjai dinilai belum transparan dan masih sering terjadi kecurangan dalam pelayanan izin usaha, tindakan nepoteisme dan sistem kekeluargaan sering terjadi, penyogokan atau penyuapan terjadi sehingga membuat masyarakat kecewa terhadap pelayanan izin usaha tersebut, tindakantindakan kelalaian ini dapat merusak citra instansi badan penanaman modal dan pelayanan perizinan Kabupaten Sinjai, kurangnya pengawasan dan kesadaran aparat membuat tindakan kecurangan terus terjadi.

\section{B. KERANGKA KONSEP}

Konsep transparansi adalah merupakan nilai utama dari sistem pemerintahan. Konteks utama aktifitas pemerintah harus diyakini berdasarkan pada transparansi. Terdapat kekuatan publik yang menuntut transparansi yang lebih besar. Pada hakekatnya ada kaitannya dengan percepatan dan pengaruh terhadap organisasi swasta, sebagaimana terus meningkatnya populasi masyarakat. Ini berarti tuntutan publik terhadap transparansi sudah semakin kuat.

Adapun Indikator transparansi yaitu prinsip yang menjamin akses atau kebebasan bagi setiap orang untuk memperoleh informasi tentang penyelenggaraan pemerintahan, yakni informasi mengenai kebijakan, proses pembuatan, pelaksanaan,dan hasil yang dicapai. Menurut Mardiasmo (2004:17) bahwa prinsip ini menekankan beberapa aspek yaitu: (1) Komunikasi publik oleh pemerintah; (2) Hak masyarakat terhadap akses informasi; (3) Penyediaan informasi yang jelas tentang tanggung jawab; (4) Kemudahan akses informasi; (5) Menyusun suatu mekanisme pengaduan jika ada peraturan yang dilanggar atau permintaan untuk membayar uang suap; dan (6) Meningkatkan arus informasi melalui kerjasama dengan media massa dan lembaga non pemerintah.

Transparansi adalah adanya kebijakan terbuka bagi pengawasan. Sedangkan yang dimaksud dengan informasi adalah informasi mengenai setiap aspek kebijakan pemerintah yang dapat dijangkau publik. Keterbukaan informasi diharapkan akan menghasilkan persaingan politik yang sehat, toleran, dan kebijakan dibuat beradsarkan preferensi publik. Makna dari transparansi dalam penyelenggaraan pemerintahan daerah dapat dilihat dalam dua hal yaitu: (1) Salah satu wujud pertanggung jawaban pemerintah kepada rakyat, dan; (2) Upaya peningkatan manajemen pengelolaan dan penyelenggaraan pemerintahan yang baik dan mengurangi kesempatan praktek kolusi, korupsi dan nepotisme (KKN). 
Menurut Minangsari (2005). Transparansi berarti terbukanya akses bagi semua pihak yang berkepentingan terhadap setiap informasi terkait seperti berbagai peraturan dan perundangundangan, serta kebijakan pemerintah dengan biaya yang minimal. Informasi sosial, ekonomi, dan politik yang handal (reliable) dan berkala haruslah tersedia dan dapat diakses oleh publik (biasanya melalui filter media massa yang bertanggung jawab). Artinya, transparansi dibangun atas pijakan kebebasan arus informasi yang memadai disediakan untuk dipahami dan (untuk kemudian) dapat dipantau.

Transparansi jelas mengurangi tingkat ketidakpastian dalam proses pengambilan keputusan dan implementasi kebijakan publik. Sebab, penyebarluasan berbagai informasi yang selama ini aksesnya hanya dimiliki pemerintah dapat memberikan kesempatan kepada berbagai komponen masyarakat untuk turut mengambil keputusan.Oleh karenanya, perlu dicatat bahwa informasi ini bukan sekedar tersedia, tapi juga relevan dan bisa dipahami publik. Selain itu, transparansi ini dapat membantu untuk mempersempit peluang korupsi di kalangan para pejabat publik dengan "terlihatnya" segala proses pengambilan keputusan oleh masyarakat luas. Dalam impelmentasi di pemerintah daerah Seringkali kita terjebak dalam "paradigma produksi" dalam hal penyebarluasan informasi ini; seakanakan transparansi sudah dilaksanakan dengan mencetak leaflet suatu program dan menyebarluaskannya ke setiap kantor kepala desa, atau memasang iklan di surat kabar yang tidak dibaca oleh sebagian besar komponen masyarakat.

Pola pikir ini perlu berubah menjadi“paradigma pemasaran", yaitu bagaimana masyarakat menerima informasi dan memahaminya. Untuk mewujudkannya dalam pelaksanaan administrasi publik sehari-hari, terdapat beberapa hal yang perlu diperhatikan:

Pertama, kondisi masyarakat yang apatis terhadap program-program pembangunan selama ini membutuhkan adanya upaya - upaya khusus untuk mendorong keingintahuan mereka terhadap data informasi ini. Untuk itu, dibutuhkan adanya penyebarluasan (diseminasi) informasi secara aktif kepada seluruh komponen masyarakat, tidak bisa hanya dengan membuka akses masyarakat terhadap informasi belaka.

Kedua, pemilihan media yang digunakan untuk menyebarluaskan informasi dan substansi materi informasi yang disebarluaskan sangat bergantung pada segmen sasaran yang dituju. Informasi yang dibutuhkan oleh masyarakat awam sangat berbeda dengan yang dibutuhkan oleh organisasi nonpemerintah, akademisi, dan anggota DPRD, misalnya. Selain itu, seringkali cara-cara dan media yang sesuai dengan budaya lokal jauh lebih efektif dalam mencapai sasaran daripada "media modern" seperti televisi dan surat kabar.

Ketiga,seringkali berbagai unsur no npemerintah misalnya pers, lembaga keagamaan, lembaga swadaya masyarakat (LSM) lebih efektif untuk menyebarluaskan informasi daripada dilakukan pemerintah sendiri.

Keterbukaan adalah keadaan yang memungkinkan ketersediaan informasi yang dapat diberikan dan didapat oleh masyarakat luas.Keterbukaan merupakan kondisi yang memungkinkan partisipasi masyarakat dalam kehidupan bernegara. Di samping itu, keterbukaan juga akan mengakibatkan batas-batas teritorial suatu negara menjadi kabur. Kecanggihan teknologi dan informasi membuat batasbatas teritorial suatu negara menjadi tidak berarti. Seseorang akan dengan mudah memberikan dan menerima informasi sesuai dengan keinginannya. 
Pada akhirnya keterbukaan akan mengakibatkan hilangnya diferensiasi (perbedaan) sosial. Akan tetapi, keterbukaan akan mempengaruhi berbagai aspek kehidupan di suatu negara. Dilihat dari aspek sosial budaya, keterbukaan akan memberikan ruang gerak bagi masuknya budaya-budaya barat yang sama sekali berbeda dengan budaya masyarakat Indonesia. Dilihat dari aspek ideologi, keterbukaan akan memberikan ruang bagi tumbuh dan berkembangnya ideologi-ideologi dari luar yang tidak sesuai dengan keperibadian suatu bangsa Indonesia. Oleh sebab itu, munculnya era keterbukaan akan membawa dampak yang sangat buruk apabila kita tidak dapat mempersiapakan diri.

Keterbukaan dalam pengertian sikap dan perilaku yang dilakukan pemerintah dewasa ini merupakan tuntutan yang tidak dapat dihindari. Sebagai contoh adalah keterbukaan arus informasi di bidang hukum.atau kepemerintahan yang demokratis maka hal yang paling utama Keterbukaan arus informasi di bidang hukum penting agar setiap warga negara mendapatkan suatu jaminan keadilan. Sikap keterbukaan juga menuntut komitmen masyarakat dan mentalitas aparat dalam melaksanakan peraturan tersebut. Kesiapan infrastruktur fisik dan mental aparat sangat menentukan jalannya "jaminan keadilan".

Dalam mewujudkan suatu pemerintahan yang harus diwujudkan oleh pemerintah adalah transparansi (keterbukaan). Adapun indikasi dari suatu pemerintahan atau ke pemerintahan yang transparan (terbuka) adalah apabila di dalam penyelenggara pemerintahannya terdapat kebebasan aliran informasi dalam berbagai proses kelembagaan. Berbagai informasi harus disediakan secara memadai dan mudah dimengerti sehingga dapat digunakan sebagai alat monitoring dan evaluasi. Kepemerintahan yang tidak transparan, cepat atau lambat cenderung akan menuju kepemerintahan yang korup, otoriter, atau diktator.

Konsep transparansi menurut, Barrington Moore (1967) adalah diantara pakar yang sejak awal mengatakan bahwa masyarakat demokratis mensyaratkan tiga hal pokok, yaitu: (1) Sistem pengawalan (checks) yang efektif terhadap pemegang kekuasaan; (2) Mekanisme untuk mengganti penguasa yang sudah tidak absah lagi; dan (3) Partisipasi dari masyarakat awam untuk menentukan berbagai peraturan.

Dari ketiga hal mendasar ini tersirat bahwa kontrol terhadap kekuasaan, dan dalam artian praktis pelaksanaan pelayanan publik yang merupakan penggunaan kekuasaan itu sendiri, menuntut hubungan yang sehat antara birokrasi publik dan masyarakat yang antara lain dapat ditunjang dengan adanya transparansi. Pada umumnya transparansi menyangkut masalah keterbukaan informasi, sesuatu yang cenderung bersifat timpang di dalam masyarakat. Dalam hal ini informasi itu sendiri dapat dirumuskan sebagai "resources of knowledge and competence that can be used byindividuals for enhancing their economic welfare, political power, or social status" Masyarakat yang diperintah secara otoriter, transparansi cenderung diabaikan atau dengan sengaja dihambat oleh pihak penguasa.

Betapapun banyak bukti yang menunjukkan bahwa ketimpangan informasi sebagai sumber daya yang sangat penting di abad 21 terkadang mengakibatkan ketimpangan kemakmuran dan kesejahteraan bagi masyarakat. Kurangnya transparansi akan mengakibatkan ketimpangan informasi. Logika ini juga didukung oleh 
teori-teori modern yang dikemukakan oleh para pakar ekonomi.

Menurut Budi (1999), pada dasarnya pemerintah di negara-negara demokrasi telah menyadari bahwa terciptanya keterbukaan dalam memperoleh informasi bagi publik dapat memberikan dampak positif bagi kehidupan sosial, politik, ekonomi, dan hukum di Negaranya, kererbukaan informasi dalam penyelenggaraan pemerintah juga merupakan salah satu wujud komitmen pemerintah dalam melaksanakan prinsip-prinsip good governance dan demokratisasi pemerintahan, di mana salah satu butir di antara butir-butir good governance adalah keterbukaan pemerintah kepada masyarakat. Keterbukaan akses informasi bagi publik di sisi lain dapar juga menjadi salah satu alat penunjang kontrol masyarakat atas kinerja pemerintah ataupun unit-unit kerjanya.

Arus informasi yang lebih baik menghasilkan pemerintah yang efektif dan membantu pengembangan yang lebih fleksibel kerjasama antara publik dan pemerintah akan semakin erat karena informasi yang semakin banyak tersedia, informasi dapat di gambarkan sebagai oksigen dalam suatu negara demokrasi terkait dengan pertanggung jawaban dan tata pemerintahan yang baik, rakyat di harapkan dapat berpartisipasi aktif dalam penyelenggaraan negara, karena itu pemberian hak kepada rakyat atas informasi merupakan tiang penyangga paling penting bagi dem okrasidan meningkatkan integritas, profesionalisme dan tanggung jawab dan penyelenggaraan Negara serta memeberdayakan masyarakat untuk melakukan kontrol sosial secara kostruktif dan efektif.

Menurut Stiglitz (2005), kerugian ekonomi (economic losses) dalam masyarakat dapat disebabkan oleh informasi yang asimetris atau informasi yang kurang sempurna. Dengan demikian, informasi semestinya juga harus diperlakukan sama pentingnya dengan uang, aset, modal atau sumberdaya lainnya. Selanjutnya, dari aspek politik atau administratif, makna transparansi akan menunjang tiga hal mendasar yaitu: (1) Meningkatnya tanggungjawab para perumus kebijakan terhadap rakyat sehingga kontrol terhadap para politisi dan birokrat akan berjalan lebih efektif; (2) Memungkinkan berfungsinya sistem kawal dan imbang (checks and balances) sehingga mencegah adanya monopoli kekuasaan oleh para birokrat; dan (3) Mengurangi banyaknya kasus korupsi.

Meningkatkan efisiensi dalam penyelenggaraan pelayanan publik. Tampak bahwa salah satu implikasi penting dari transparansi ialah peluang untuk meningkatkan efisiensi dalam pelaksanaan pelayanan publik. Di dalam praktik akan terlihat bahwa sistem dan prosedur pelayanan publik yang transparan akan meningkatkan komitmen para birokrat dan selanjutnya akan memperbaiki kualitas pelayanan publik secara keseluruhan.

Menurut Agus Dwiyanto (2003:28). Transparansi yakni adanya kebijakan terbuka bagi pengawasan.Sedangkan yang dimaksud dengan informasi adalah informasi mengenai setiap aspek kebijakan pemerintah yang dapat dijangkau oleh publik. Keterbukaan informasi diharapkan akan menghasilkan persaingan politik yang sehat, toleran, dan kebijakan dibuat berdasarkan pada preferensi publik. Prinsip ini memiliki 2 aspek, yaitu (1) komunikasi publik oleh pemerintah, dan (2) hak masyarakat terhadap akses informasi. Keduanya akan sangat sulit dilakukan jika pemerintah tidak menangani dengan baik kinerjanya. Manajemen kinerja yang baik adalah titik awal dari transparansi. Komunikasi publik menuntut usaha afirmatif dari 
pemerintah untuk membuka dan mendiseminasi informasi maupun aktivitasnya yang relevan.

Berkaitan dengan pelayanan masyarakat, dalam era globalisasi, pemerintah harus mempersiapkan seluruh aparatnya untuk meningkatkan kualitas pelayanan dan sopan santun ini merupakan syarat mutlak untuk menjaga citra instansinya. Oleh karena itu perlu dijaga agar jangan sampai terjadi hal-hal yang bisa menyinggung perasaan masyarakat yang dilayaninya.

Setiap orang menginginkan jasa pelayanan yang diterima dan yang dirasakan sesuai dengan harapannya. Secara umum masyarakat menginginkan pelayanan yang sama dari aparatur pemerintah,sebab warga negara yang mempunyai kedudukan yang sama di dalam hukum berhak mendapatkan pelayanan yang sama. Pelayanan yang bersahabat dan profesional sudah menjadi suatu syarat yang harus dipenuhi oleh para pelanggan pekerjaan administrasi negara.

Menurut Abdul Hafis (2000:40). Prinsip keterbukaan mengandung arti bahwa prosedur tata cara, persyaratan, satuan kerja pejabat penanggung jawab pemberi pelayanan, waktu penyelesaian, rincian biaya atau tarif serta hal-hal lain yang berkaitan dengan proses pelayanan wajib diinformasikan secara terbuka agar mudah diketahui dan dipahami oleh masyarakat, baik diminta maupun tidak diminta. Prinsip keterbukaan pelayanan memberikan petunjuk untuk menginformasikan secara terbuka segala sesuatu yang berkaitan dengan pelaksanaan pemberian pelayanan kepada masyarakat. Untuk itu yang perlu diupayakan dalam prinsip ini, ialah: Penginformasian instrumen pelayanan secara terbuka (seperti: bagan alur mekanisme pelayanan, daftar persyaratan, daftar tarif, jadwal waktu, nama loket, petugas, meja kerja).
Selanjutnya menurut Fitzmmons (dalam Budiman, 2006:23) berpendapat terdapat indikator pelayanan yaitu sebagai berikut: kehandalan yaitu kemampuan untuk memberikan pelayanan sesuai dengan janji yang ditawarkan.

Daya tanggap yaitu respon karyawan dalam membantu konsumen dan memberikan pelayanan yang cepat dan tanggap, yang meliputi respon dalam melayani konsumen, kecepatan menangani transaksi, dan penanganan keluhan-keluhan konsumen: Jaminan, meliputi kemampuan karyawan atas pengetahuan terhadap produk secara tepat, kualitas keramahtamahan, perhatian dan kesopanan dalam memberi pelayanan, keterampilan dalam memberi informasi, kemampuan dalam memberik an keamanan di dalam memanfaatkan jas a yang ditawarkan, dan kemampuan dala m menanamkan kepercayaan konsumen terhadap perusahaan; dan (2) Empati yaitu perhatian secara individual yang diberikan perusahaan kepada konsumen seperti kemudahan untuk menghubungi perusahaan,

kemampuan karyawan untuk berkomuni kasi dengan konsumen, dan usaha perusahaan untuk memahami keinginan dan kebutuhan konsumennya.

Pelayanan adalah suatu bentuk kegiatan pelayanan yang dilaksanakan oleh instansi pemerintah baik di pusat dan daerah maupun BUMN dan BUMD dalam rangka pemenuhan kebutuhan masyarakat sesuai peraturan perundangundangan yang berlaku. Dalam kamus besar bahasa Indonesia dinyatakan bahwa pelayanan publik adalah suatu usaha untuk membantu menyiapkan (mengurus) apa yang diperlukan orang lain.

Pelayanan publik atau pelayanan umum dapat didefinisikan sebagai segala bentuk jasa pelayanan, baik dalam bentuk barang publik maupun jasa publik yang 
pada prinsipnya menjadi tanggung jawab dan dilaksanakan oleh Instansi Pemerintah di pusat, di daerah, dan di lingkungan Badan Usaha Milik Negara atau Badan Usaha Milik Daerah, dalam rangka upaya pemenuhan kebutuhan masyarakat maupun dalam rangka pelaksanaan ketentuan peraturan perundang-undangan.

Pelaksanaannya pelayanan dilakukan secara pelayanan profesional, dan prima artinya dilakukan secara konkrit bahwa yang melayani harus memiliki suatu kemampuan dalam melayani, menanggapi kebutuhan khas (unik, khusus, istimewa) orang lain agar mereka puas. Pelayanan prima merupakan pelayanan yang memenuhi standar pelayanan terhadap permintaan, keinginan, dan harapan masyarakat yang mempunyai nilai yang tinggi dan bermutu (berkualitas). Selain peningkatan pelayanan prima, pelayanan yang berkualitas juga dapat dilakukan dengan konsep "layanan sepenuh hati". Layanan sepenuh hati yang digagas oleh Patton Patricia dimaksudkan layanan yang berasal dari diri sendiri yang mencerminkan emosi, watak, keyakinan, nilai, sudut pandang, dan perasaan. Oleh karena itu aparatur pelayanan dituntut untuk memberikan layanan kepada pelanggan dengan sepenuh hati. Layanan seperti ini tercermin dari kesungguhan aparatur untuk melayani. Kesungguhan yang dimaksudkan, aparatur pelayanan menjadikan kepuasan pelanggan sebagai tujuan utamanya.

Pelayanan publik adalah pelayanan yang diberikan oleh Negara ataupun daerah dan perusahaan milik negara kepada masyarakat untuk memenuhi kebutuhan dasarnya dalam rangka menciptakan kesejahteraan masyarakat. Pelayanan perizinan dengan sistem terpadu satu pintu (one stop service) ini membuat waktu pembuatan izin menjadi lebih singkat. Pasalnya, dengan pengurusan administrasi berbasis teknologi informasi, input data cukup dilakukan sekali dan administrasi bisa dilakukan simultan.

Dengan adanya kelembagaan pelayanan terpadu satu pintu, seluruh perizinan dan nonperizinan yang menjadi kewenangan kabupaten/kota dapat terlayani dalam satu lembaga. Harapan yang ingin dicapai adalah mendorong pertumbuhan ekonomi melalui peningkatan investasi dengan memberikan perhatian yang lebih besar pada peran usaha mikro, kecil, dan menengah. Tujuannya adalah meningkatkan kualitas layanan publik. Oleh karena itu, diharapkan terwujud pelayanan publik yang cepat murah, mudah, transparan, pasti, dan terjangkau, di samping untuk meningkatkan hak-hak masyarakat terhadap pelayanan publik.

Bentuk pelayanan terpadu ini bisa berbentuk kantor, dinas, ataupun badan. Dalam penyelenggaraannya, bupati/wali kota wajib melakukan penyederhanaan layanan meliputi: (1) Pelayanan atas permohonan perizinan dan non perizinan dilakukan oleh PPTSP; (2) Percepatan waktu proses penyelesaian pelayanan tidak melebihi standar waktu yang telah ditetapkan dalam peraturan daerah; (3) Kepastian biaya pelayanan tidak melebihi dari ketentuan yang telah ditetapkan dalam peraturan daerah; (4) Kejelasan prosedur pelayanan dapat ditelusuri dan diketahui setiap tahapan proses pemberian perizinan dan non perizinan sesuai dengan urutan prosedurnya; (5) Mengurangi berkas kelengkapan permohonan perizinan yang sama untuk dua atau Lebih permohonan perizinan; (6)Pembebasan biaya perizinan bagi Usaha Mikro Kecil Menengah (UMKM) yang ingin memulai usaha baru sesuai dengan peraturan yang berlaku; dan pemberian hak kepada masyarakat untuk memperoleh informasi dalam kaitannya dengan penyelenggaraan pelayanan 
Lingkup tugas PPTSP meliputi pemberian pelayanan atas semua bentuk pelayanan perizinan dan non perizinan yang menjadi kewenangan Kabupaten / Kota. (7) PPTSP mengelola administrasi perizinan dan non perizinan dengan mengacu pada prinsip koordinasi, integrasi, sinkronisasi, dan keamanan berkas. Dalam pengertian sempit, pelayanan terpadu dapat berarti sebagai satu instansi pemerintah yang memiliki semua otoritas yang diperlukan untuk memberi perbagai perizinan (licenses, permits, approvals dan clearances). Tanpa otoritas yang mampu menangani semua urusan tersebut instansi pemerintah tidak dapat mengatur perbagai pengaturan selama proses. Oleh sebab itu, dalam hal ini instansi tersebut tidak dapat menyediakan semua bentuk perizinan yang diperlukan dalam berbagai tingkat administrasi, sehingga harus bergantung pada otoritas lain.

Berdasarkan uraian di atas maka dapat disimpulkan bahwa peranan sistem pelayanan terpadu (One-Stop Service) dalam pembentukan kebijakan investasi pemerintah pasca desentralisasi One Stop Service adalah bagian dari prioritas paket kebijakan yang harus dipersiapkan daerah dalam rangka investasi. Agar investor asing tertarik untuk menanamkan modalnya di Indonesia, pemerintah daerah mengetahui perihal apa saja yang perlu dibenahi oleh daerah, dikarenakan banyaknya prioritasprioritas yang harus dipersiapkan, salah satunya adalah penguatan institusi dan kelembagaan serta kepastian hukum. Pembentukan sistem pelayanan terpadu satu pintu (one stop service) merupakan progam yang termasuk di dalamnya. Oleh karena itu pemerintah daerah wajib memberikan pelayanan perorangan dengan biaya murah, cepat dan baik, harus mendapatkan pelayanan yang sama.
Di samping itu juga harus diperlakukan oleh petugas dengan sikap yang sopan dan ramah. Semua orang tanpa kecuali baik kaya, miskin, pejabat, orang biasa, orang desa atau kota, harus diperlakukan sama. Tidak boleh dibedabedakan baik dengan sikap, biaya maupun waktu penyelesaian. Pelayanan pemerintah daerah kepada khalayak juga harus adil dan merata.

Tujuan dari pelayanan prima adalah memuaskan dan atau sesuai dengan keinginan pelanggan. Untuk mencapai hal itu, diperlukan kualitas pelayanan yang sesuai dengan kebutuhan dan atau keinginan pelanggan: (1) Kualitas pelayanan meliputi dimensi-dimensi berikut: Ketaatan waktu pelayanan, berkaitan dengan waktu tunggu dan waktu proses; (2) Akurasi pelayanan, berkaitan dengan keakuratan pelayanan dan bebas dari kesalahan-kesalahan; (3) Kesopanan dan keramahan dalam memberikan pelayanan, berkaitan dengan prilaku orang-orang yang berintegrasi langsung kepada pelanggan eksternal; (4) Tanggung jawab, berkaitan dengan penerimaan pesanan dan penanganan keluhan pelanggan eksternal (masyarakat); (5) Kemudahan mendapatkan pelayanan, berkaitan dengan banyaknya petugas yang melayani dan fasilitas pendukung; dan

(6) Kenyamanan mendapat pelayanan, berkaitan dengan lokasi, ruangan tempat pelayanan, tempat parkir, ketersediaan informasi dan petunjuk panduan lainnya.

Selanjutnya pengertian penanaman modal asing menurut Undang-undang Nomor 25 Tahun 2007 pasal 1 ayat 3 adalah kegiatan penanaman modal untuk melakukan usaha di wilayah Negara Repoblik Indonesia yang dilakukan penanam modal asing, baik yang menggunakan model asing sepenuhnya atau yang berpatungan dengan penanam modal dalam negri. Ketentuan pasal 1 ayat 3 mengandung beberapa unsur 
yaitu: Penanaman modal secara langsung (direct investment) Penanaman modal untuk menjalankan perusahaan di Indonesia.

Jenis jenis Penanaman Modal, Pada dasarnya kegiatan penanaman modal diklasifikasikan atas dua kategori besar yaitu:

1) Investasi langsung (Direct Invenstment) atau penaman modal modal jangka panjang;

Di dalam undang-undang penanaman modal, pengertian penanaman modal hanya mencakup penanaman modal secara langsung dalam kaitan dengan penelolaan modal. Dalam menanamkan modal yang melibatkan investor secara langsung dapat dilakukan melalui beberapacara penanaman modal, seperti investasi-investasi dalam bentuk: (1) Modal sendiri (equity);(2) Modal dari dana pinjaman (loan); (3) Modal bersifatnya nyata (tangible) dan tidak nyata (intangible); (4) Modal dari keuntungan usaha (reinvestment); (5) Modal langsung (straight investment); (6) Modal patungan (joint venture, joint enterprise); (7) Partisipasi modal melalui berbagi bentuk kerja sama dalam hubungan-hubungan kontraktual.

Investasi langsung ini dapat dilakukan dengan mendirikan perusahaan patungan (joint venture company) dengan mitra lokal, melakukan kerja sama operasi (joint operation scheme) tanpa membentuk perusahaan baru, mengkonversikan pinjamaan menjadi penyertaan mayoritas dalam perusahaan lokal, memberikan bantuan dan maupun memberikan lisensi dan lain-lain: (1) Modal dari keuntungan usaha (reinvestment); (2) Modal langsung (straight investment); (3) Modal patungan (joint venture, joint enterprise); (4) Partisipasi modal melalui berbagi bentuk kerja sama dalam hubungan-hubungan kontraktual.
Investasi langsung ini dapat dilakukan dengan mendirikan perusahaan patungan (joint venture company) dengan pemerintah lokal, melakukan kerja sama operasi (joint operation scheme) tanpa membentuk perusahaan baru, mengkonversikan pinjamaan menjadi penyertaan mayoritas dalam perusahaan lokal, memberikan bantuan dan manajerial maupun memberikan lisensi dan lain-lain.

2) Investasi tidak langsung (indirect investment).

Pada umumnya dicapai kesepakatan mengenai perbedaan antara investasi langsung dan investasi tidak langsung yaitu: (1) Pada investasi tak langsung, pemegang saham tidak memiliki kontrol pada pengelolaan perseroan sehari-hari; (2) Pada investasi tak langsung, resiko ditanggung sendiri oleh pemegang saham sehingga pada dasarnya tidak dapat mengugat perusahaan yang menjalankan kegiatanya; (3) Kerugian pada investasi tak langsung, pada umumnya tidak dilindungi oleh hukum kebiasaan internasional (international customary law).

Investasi tidak langsung umumnya merupakan penanaman modal jangka pendek yang mencakup kegiatan transaksi dipasar modal dan dipasar uang. Penanaman modal ini disebut penanaman modal jangka pendek karena pada umumnya mereka melakukan jual beli saham dan atau mata uang dalam jangka waktu yang relatif singkat, tergantung fluktuasi nilai saham dan atau mata uang yang hendak mereka perjual belikan.

Asas penanaman modal 'menginspirasi' pembentukan pasal-pasal sehingga pasal-pasal mencerminkan keberadaan asas hukum yang bersifat abstrak normatif. Lebih lanjut asas penanaman modal yang terdapat dalam pasal 3 ayat 1 adalah: 
a. Asas kepastian hukum; adalah asas dalam negara hukum yang meletakan hukum dan ketentuan peraturan perundang-undagan sebagai dasar dalam setiap kebijakan dan tindakan dalam bidang penanaman modal;

b. Asas keterbukaan; adalah asas yang terbuka terhadap hak masyarakat untuk memperoleh informasi yang benar, jujur, dan tidak diskriminatif tentang kegiatan penanaman modal;

c. Asas akuntabilitas; adalah asas yang menentukan setiap kegiatan dan hasil akhir dari penyelenggaran penanaman modal harus dipertanggung jawabkan kepada masyarakat atau rakyat sebagai pemegang kedaulatan tertinggi negara sesuai ketentuan peraturan perundang-undangan;

d. Asas perlakuan yang sama tidak membedakan asal negara; adalah asas perlakuan pelayanan nondiskriminasi berdasarkan ketentuan perundang-undagan, baik antara penanaman modal dalam negri dan penanaman modal asing maupun antara penanaman modal dari satu negara asing dan penanaman modal dari negara asing lainya;

e. Asas kebersamaan; adalah asas yang mendorong peran seluruh penanaman modal secara bersamasama dalam kegiatan usahanya untuk mewujudkan kesejahteraan rakyat;

f. Asas efisiensi berkeadilan; adalah asas yang mendasari pelaksanan penanaman modal dengan mengedepankan efisiensi berkeadilan dalam usaha untuk mewujudkan iklim usaha yang adil, kondusif dan berdaya asing.

Pasal 3 ayat 2 Undang-Undang penanaman modal 25 Tahun 2007 menentukan tujuan penyelenggaraan penanaman modal menentukan tujuan penyelenggaraan penanaman modal adalah: (1) Meningkatkan pertumbuhan ekonomi nasional; (2) Menciptakan lapangan kerja; (3) Meningkatkan pembangunan ekonomi berkelanjutan; (4) Meningkatkan kemampuan daya asing dunia usaha nasional; (5) Mendorong pengembangan ekonomi kerakyataan; (6) Mengolah ekonomi potensial menjadi kekuatan ekonomi rill menggunakan dana yang berasal, baik dari dalam negri maupun luar Negeri; (7) Meningkatkan kesejahteraan masyarakat.

Tujuan penanaman modal dijadikan acuan dalam kebijakan penanaman modal oleh badan koordinasi penanaman modal, departemen teknis terkait, dan pemerintahan daerah. Tujuan harus mampu mengarahkan kebijakan dasar penanaman modal sesuai ketentuan pasal 4 Undang-undang penanaman modal. Tujuan utama penanaman modal dalam Undang-Undang Nomor 25 tahun 2007 tentang penanaman modal antara lain:

a) Sebagai bentuk kepastian hukum terhadap ketidak pastian yang terkait dengan kegiatan investasi;

b) Untuk memperbaiki image investasi dalam negeri sehingga menjadikan indonesia tidak hanya menjadi pasar bagi produk-produk asing, tetapi sebagai tempat yang layak untuk melakukan investasi.

Tata Cara Penanaman Modal dan Pemberian Sanksi. Penanaman modal adalah segala bentuk kegiatan penanaman modal, baik oleh penanaman modal asing untuk melakukan usaha diwilayah negara Repoblik Indonesia. Berdasarkan Undang-Undang Nomor 25 Tahun 2007, penanaman modal dalam negri dapat dilakukan dalam bentuk badan usaha yang berbentuk badan hukum dan badan usaha yang tidak berbadan hukum atau usaha perseorangan. Penanaman modal asing wajib dalam bentuk perseroan terbatas berdasarkan hukum Indonesia. Permohonan penanaman modal baik 
permohonan penanaman modal dalam negeri maupun penanaman modal asing diatur dalam pelayanan terpadu satu pintu untuk melaksanakan ketentuan pasal 26 ayat 3 Undang-Undang No.25 tahun 2007, yang di tetapkan dengan peraturan presiden Nomor 27 tahun 2009 tentang pelayanan Terpadu Satu Pintu di Bidang Penanaman Modal.

Tujuan pedoman dan tata cara penanaman modal di dalam pasal 2 ayat 2 adalah:

1. Terwujudnya kesamaan dan keseragaman atas prosedur dan proses penyelesaian permohonan penanaman modal;

2. Memberikan gambaran umum dan kepastian waktu penyelesaiaan permohonan prizinan dan nonperizinan penanaman modal.

\section{METODE PENELITIAN}

Penelitan ini memilih lokasi di kabupaten sinjai selatan. Jenis penelitian yang digunakan adalah pendekatan deskriptif Kuantitatif dan kualitatif adalah pendekatan yang mementingkan adanya variabel - variabel sebagai obyek penelitian dan variabel tersebut didefinisikan dalam bentuk operasionalisasi variabel masing-masing yang disajikan dalam bentuk tabel frekuensi dan distribusi. Populasi dan sampel dalam penelitian ini adalah. Kepala badan, Bidang informasi pengaduan, masyarakat yang mengurus dimana sampel terdiri dari kepala badan 1 orang, bidang informasi pengaduaan 4 orang, masyarakat yang mengurus 30 . jadi jumlah keseluruhan sampel dalam penelitan ini 35 orang. Adapun teknik pengumpulan data yang digunakan yaitu (Observasi) yaitu pengumpulan data yang dilakukan dengan cara melakukan pengamatan langsung terhadap Transparansi Pelayanan Izin Investasi Usaha di Badan Penanaman Modal dan Pelayanan Perizinan di Kabupaten Sinjai, wawancara (Interview) yaitu mengajukan pertanyaan langsung kepada responden yang berkaitan Transparansi Pelayanan Izin Investasi Usaha di Badan Penanaman Modal dan Pelayanan Perizinan di Kabupaten Sinjai, kuesioner (Angket) yaitu teknik pengumpulan data yang dilakukan dengan cara membuat daftar pertanyaan yang diedarkan kepada responden yang berkaitan dengan permasalahan yang diteliti yaitu mengenai.

Transparansi Pelayanan Izin Investasi Usaha di Badan Penanaman Modal Dan Pelayanan Perizinan di Kabupaten Sinjai. Teknik analisis data yang digunakan dalam penelitian ini adalah Dalam penelitian ini, peneliti mengumpulkan dua jenis data yaitu kuantitatif dan data kualitatif, Kemudian dianalisis secara Setelah data terkumpul, maka perlu diolah sesuai dengan sifatsifatnya. Maksudnya data bersifat kuantif diolah dengan cara menggunakan tabulasi persentase dan nilai rata-rata (Mean) dengan rumus, Keabsahan data dalam penelitian ini diperiksa dengan menggunakan teknik triangulasi. Triangulasi bermakna silang yakni mengadakan pengecekan akan kebenaran data yang akan dikumpulkan dari sumber data dengan menggunakan teknik pengumpulan data yang lain serta pengecekan pada waktu yang berbeda.

\section{HASIL DAN PEMBAHASAN}

\section{Transparansi pelayanan izin investasi usaha dibadan penanaman modal dan pelayan perizinan di Kabupaten Sinjai.}

\section{1) Keterbukaan Proses Pelayanan}

Transparansi menunjuk pada suatu keadaan dimana segala aspek dari proses penyelenggaraan pelayanan bersifat terbuka dan dapat diketahui dengan mudah oleh para pelanggan izin investasi usaha. Jika segala aspek proses penyelenggaraan pelayanan seperti 
persyaratan, biaya dan waktu yang diperlukan, cara pelayanan, serta hak dan kewajiban penyelenggara dan pengguna layanan dipublikasikan secara terbuka sehingga mudah diakses dan dipahami oleh masyarakat, maka praktik penyelenggaraan pelayanan itu dapat dinilai memiliki transparansi yang tinggi.

Pada indikator keterbukaan proses pelayanan yang memadai, terdapat kategori yang sangat transparan,terdapat 20 orang (57.1\%) yang memberi tanggapan transparan, terdapat 10 orang (28.5\%) yang memberi tanggapan cukup transparan, terdapat 5 orang (14.2). Berikut hasil kutipan wawancara dengan responden terkait dengan indikator transparansi pelayanan izin investasi usaha seperti berikut ini:

"Saya rasa apa yang dilakukan Kantor Badan Penanaman Modal Dan Perizinan tentang transparansi pelayanan izin usah sudah sangat terbuka pada masyarakat yang mengurus, karena informasi yang secara memadai tentang Pelayanan Izin Usaha sudah sangat transparan dan dirasakan oleh saya maupun pelanggan yang mengurus izin usaha". (Wawancara AM).

2) Kemudahan memperoleh informasi

Kemudahan memperoleh informasi adalah kemudahan masyarakat di dalam memperoleh informasi baik secara langsung maupun tidak langsung. Akses informasi secara langsung yaitu informasi yang didapatkan dengan langsung berhadapan dengan pihak terkait mengenai informasi yang dibutuhkan. Informasi tidak langsung adalah informasi yang didapatkan melaui media perantara seperti pengumuman lewat IT, brosur, pamplet dan lain-lain.

Pada indikator memperoleh informasi secara langsung, terdapat 5 orang $(14,2 \%)$ yang memberi tanggapan sangat mudah, terdapat 19 orang (54.2\%) yang memberi tanggapan mudah, terdapat 5 orang $(14,2 \%)$ yang memberi tanggapan cukup mudah, dan terdapat 6 orang (17.1\%) yang memberi tanggapan sulit. Kategori terbesar berada pada kategori mudah sebanyak 19 orang.

Berikut hasil kutipan wawancara dengan responden terkait dengan indikator memperoleh informasi secara langsung seperti berikut ini:

"Informasi yang dapat kita akses secara langsung tentang kemusahan akses informasi dalam perizinan cukup mudah yaitu dengan adanya bagianbagian yang menangani tiaptiap loket, menggambarkan transparansi ataupun keterbukaan. Dan jika pelanggang ke kantor untuk mendapatkan informasi yang diinginkan pasti kami berikan, selama itu tidak melanggar aturan, hanya saja terkadang masyarakat tidak mengerti dan tidak melihat kondisi". (Wawancara).

\section{3) Proses Pembuatan Kebijakan}

Seperti halnya dialam proses pembuatan kebijakan adanya kebijakan yang terbuka bagi pengawasan, proses pembuatan pelaksanan dan hasil melalui mekanisme seperti ini tidak hanya mewujudkan transparansi pemerintahan akses masyarakat terhadap informasi pun terpenuhi bahkan mampu menjadi sarana untuk mengoptimalkan pengawasan masyarakat terhadap penyelenggaraan pemerintah,dan pihak kantor pun mengatakan bawha tahun ini pihaknya akan melakukan pelayanan perizinan langsung kepada masyarakat bekerja sama dengan SKPD terkait serta pihak kecamatan dan pemerintah desa.

Pada indikator memperoleh informasi secara tidak langsung, tidak terdapat tanggapan pada kategori sangat mudah, terdapat 20 orang (57.1\%) yang 
memberi tanggapan mudah, terdapat 10 orang $(28.5 \%)$ yang memberi tanggapan cukup mudah, dan terdapat 5 orang (14.2\%) yang memberi tanggapan sulit. Kategori terbesar berada pada kategori mudah sebanyak 20 orang (57.1\%).

Berikut hasil kutipan wawancara dengan responden terkait dengan indikator memperoleh informasi secara tidak langsung seperti berikut ini:

"Penyediaan informasi melalui media, baik itu media cetak maupun media elektronik merupakan salah satu bentuk layanan dari sebuah instansi. Terkait dengan akses informasi pelayanan izin investasi usaha, yang dilakukan melalui media adalah salah satu bentuk tanggung jawab yang baik. Tetapi informasi melalui media sering terkendala masalah teknis seperti jaringan dan tidak semua pihak mampu menggunakan IT". (Wawancara Af).

4) Kepuasan Masyarakat

Kepuasan masyarakat adalah bagaimana cara pegawai izin usaha memberikan layanan kepada masyarakat atau pelanggan untuk memenuhi keinginan dan kebutuhan pelanggan dengan tujuan meningkatkan kesejahteraan sehingga masyarakat merasa puas dengan layanan yang telah diberikan.

Berdasarkan data yang dihimpun dari responden menunjukan bahwa terdapat tanggapan sangat puas sebanyak 24 orang $(68.5 \%)$, cukup puas sebanyak 8 orang $(22.5 \%)$, kurang puas sebanyak 3 orang $(8.5 \%)$, tidak terdapat tanggapan pada kategori tidak puas Kondisi ini menunjukan bahwa tanggapan responden didomisili oleh tanggapan yang cukup puas yaitu sebanyak 24 orang $(68.5 \%)$.
Berikut hasil wawancara dengan responden terkait kepuasan masyarakat dalam menerima layanan seperti berikut ini : "saya sangat puas atas pelayanan yang telah diberikan oleh pegawai Badan Penanaman modal disini di dalam melayani izin investasi usaha sudah memberikan pelayanan sepenuh hati". (Wawancara).

\section{Upaya Dilakukan Dalam Pengeloaan Pelayanan Izin Usaha Agar Transparan Di Badan Penanaman Modal Dan Pelayanan Perizinan Di Kabupaten Sinjai.}

Upaya pemerintah daerah untuk memberikan pelayanan publik yang optimal kepada masyarakat dan menjadi sangat penting untuk dilakukan kegiatan workshop ini merupakan agenda pengembangan pelayanan yang ada pada Badan Penanaman Modal Dan Pelayanan Perizinan di Kabupaten Sinjai.

Selain itu, beberapa upaya pemerintah agar kinerja kerjanya dikatakan transparan yakni integritas dimana suatu nilai atau kejujuran dalam sebuah wadah atau tempat dimana terlaksanaya suatu proses pelayanan diantaranya adalah pelayanan publik,dan dimana terdapat juga profesionalisme adalah dimana tingakah laku atau keahlian seseorang didalam mengatur suatu sistem yag ada dalam proses kerja tersebut,dan ada juga tentang konstruktif yang dimana membangun kesadaran pegawai yang bersifat membina dan membangun dan memperbaiki sehingga didalam proses pelayanan akan terjadi transparansi,dalam suatu berjalanya proses pelayanan tidak jauh dari efektif yang dimana kemampuan akan terlaksananya tugas dan fungsi pelayanan yang terbuka. Dengan demikian, informasi semestinya juga harus diperlakukan sama pentingnya dengan 
uang, aset, modal atau sumberdaya lainnya. Selanjutnya, dari aspek politik atau administratif, makna transparansi akan menunjang empat hal yang mendasar yaitu: (1) Meningkatnya tanggungjawab para perumus kebijakan terhadap rakyat sehingga kontrol terhadap para politisi dan birokrat akan berjalan lebih efektif; (2) Memungkinkan berfungsinya sistem kawal dan imbang (checks and balances)sehingga mencegah adanya monopoli kekuasaan oleh para birokrat; (3) Mengurangi banyaknya kasus korupsi; (4) Meningkatkan efisiensi dalam penyelenggaraan pelayanan publik.

\section{E. PENUTUP}

Berdasarkan hasil pengamatan penulis, indikator keterbukaan proses pelayanan dipahami sebagai prosedur pelayanan informasi dan kemudahan memperoleh informasi telah dilakukan secara transparan sesuai dengan keinginan masyarakat. Kedua, upaya pemerintah agar transparan dalam penanaman modal dan pelayanan perizinan dengan indikator yaitu: integritas suatu nilai atau kejujuran dalam sebuah wadah atau tempat dimana terlaksanaya suatu proses pelayanan diantaranya adalah pelayanan publik, dan dimana terdapat juga profesionalisme dan tingkah laku atau keahlian seseorang didalam mengatur suatu sistem yag ada dalam proses kerja tersebut, dan konstruktifitas yang membangun kesadaran pegawai yang bersifat membina dan membangun dan memperbaiki sehingga didalam proses pelayanan akan terjadi transparansi, dalam suatu berjalanya proses pelayanan tidak jauh dari efektif yang dimana kemampuan akan terlaksananya tugas dan fungsi pelayanan yang terbuka.

Lebih lanjut hasil pengamatan penulis bahwa pelayanan izin investasi usaha di kantor Badan Penanaman Modal
Dan Pelayanan Perizinan Di Kabupaten Sinjai sudah dilaksanakan dengan sangat baik.

Kepuasan masyarakat mengenai pelayanan pegawai Perizinan yaitu berada pada tanggapan responden yang sangat puas, berarti pelayanan Pegawai perizinan sudah berjalan sesuai indikator transparansi.

Adapun saran-saran yang diajukan dalam penelitian ini adalah:

Pertama, Pegawai Perizinan harus lebih transparan lagi atau terbuka kepada masyarakat atau pelanggang yang mengurus izin usaha harus lebih teliti dalam pengursan atau utnuk berjalanya suatu pelayanan yang baik tidak memakai calo atau pelanggan yang turun langsung ke tepat pengurusan agar tidak ada lagi kecurigaan dalam sebuah instansi.

Kedua, pegawai perizinan sudah sangat baik dalam meningkatkan kualitas pelayanan terhadap masyarakat yang mengurus surat izin investasi usaha.

\section{DAFTAR PUSTAKA}

Barrington, Moore,1967, Public Policy for Democracy. Washinton: DC. The Brookings Institutions.

Budi, Kekuasaan, 1999. Gramedia Yokyakarta

Budiman, 2006. Reformasi Pelayanan Publik, Jakarta : Bumi Aksara.

Dwiyanto, Agus, dkk. 2003. Reformasi Tata pemerintahan dan otonomi Daerah. Yogyakarta: Pusat Studi Kependudukan dan kebijakan UGM.

Efenddi, 2005. Upaya Pemerintah Dalam Merumuskan Kebijakan, Bandung

H.A.S, Moenir, 2006, .Manajemen Pelayanan Umum di Indonesia. Jakarta: Bumi Aksara.

Hasan Iqbal, 2002, Pokok-pokok Materi Metodologi Penelitian dan 
Aplikasinya. Jakarta: Ghalia Indonesia.

Mahmoedin, H.As, 1995. Etika Pelayanan Bank. Jakarta: PT Gunung Agung.

Mardiasmo, 2004, Otonomi dan Manajemen Keuangan Daerah.Yogyakarta.Andi.

Moenir, H.A.S, 1998. Pendekatan Manusiawi dan Organisasi Terhadap Pembinaan Kepegawaian. Jakarta: Gunung Agung.

Pandji Anoraga, 1995, Perusahaan Multi Nasional Penanaman Modal Asing, Jakarta: Pustaka Jaya.

Stiglitz, 2005, The New Public Management Action.Oxford: Universitiy .Press

Sugiyono. Metode Penelitian ( Pendekatan Kualitatif, Kuantitatif, dan RND). Bandung: Alfabeta, 2013.

Supriyanto, Budi. 2009. Manajemen Pemerintahan. Tangerang : Media Brilian.

Dokumen

Peraturan PerUndang-Undangan UU Nomor 25 Tahun 2007 tentang Penanaman Modal.

Peraturan PerUndang-Undangan UU Nomor 27 Tahun 2009 Tentang Pelayanan Terpadu Satu Pintu.

Peraturan Undang-Undang No.32 Tahun 2004 Tentang Pemerintahan Daerah.

Peraturan Menteri Dalam Negeri Nomor 24 Tahun 2006 Tentang Pedoman Penyelenggaraan Pelayanan Terpadu Satu Pintu.

Peraturan Pemerintah Nomor 50 Tahun 1993 Tentang Persyaratan Pemilikan
Saham Dalam Penanaman Modal Asing..

Republik Indonesia, Undang-Undang No. 12 Tahun 2009 Tentang Pedoman dan Tata Cara Permohonan Penanaman Modal. 